\title{
Activity and diversity of bacterial cells with high and low nucleic acid content
}

\author{
Pierre Servais ${ }^{1}$, Emilio O. Casamayor ${ }^{2,3}$, Claude Courties ${ }^{2}$, Philippe Catala ${ }^{2}$, \\ Nathalie Parthuisot ${ }^{2}$, Philippe Lebaron ${ }^{2, *}$ \\ ${ }^{1}$ Ecologie des Systèmes Aquatiques, Université Libre de Bruxelles, Campus Plaine, CP 221, 1050 Bruxelles, Belgium \\ ${ }^{2}$ Observatoire Océanologique, Laboratoire ARAGO, Université Pierre et Marie Curie, UMR 7621-7628 CNRS-INSU, BP 44, \\ 66651 Banyuls-sur-Mer cedex, France \\ ${ }^{3}$ Present address: Unitat de Limnologia, Centre d'Estudis Avançats de Blanes (CSIC), Accés Cala Sant Francesc 14, \\ 17300 Blanes, Spain
}

\begin{abstract}
In most aquatic environments, at least 2 subpopulations of bacterial cells can be discriminated by flow cytometry based on their nucleic acid content. Recent investigations have shown that the cells with a high nucleic acid (HNA) content have a higher cell-specific activity (CSA) cell than those with a low nucleic acid (LNA) content. In this study, the CSA and biomass-specific activities (BSA) of HNA and LNA cells from different aquatic ecosystems, including marine, brackish and freshwater, were investigated using radioactive leucine incorporation and cell sorting by flow cytometry. The genetic diversity of natural assemblages, HNA and LNA cells was investigated using the SSCP (PCR single-strand conformation polymorphism) method. Data showed that both CSA and BSA of HNA cells were always significantly higher than CSA and BSA of LNA cells. In addition, HNA cells had a dominant contribution to the production of the total community ( 77 to $98 \%$ ). For the different samples, the SSCP fingerprints from the natural assemblage and from the 2 sorted fractions were not significantly different. This clearly suggests that HNA and LNA subpopulations were composed by the same dominant species and, thus, confirms an important heterogeneity of physiological states within most natural populations.
\end{abstract}

KEY WORDS: Nucleic acid content · Side scatter $\cdot$ Cellular activity $\cdot$ Flow cytometry $\cdot$ Cell sorting • Genetic diversity $\cdot$ Single-strand conformation polymorphism

Resale or republication not permitted without written consent of the publisher

\section{INTRODUCTION}

An important challenge in microbial ecology is to understand the role that phylogenetically defined populations play in the functioning of biogeochemical cycles. The most difficult part of this challenge is to be able to provide information on both the activity and the functional role of specific populations. This increasing interest in population ecology is due to the recent development of new methods that are available for single-cell analysis. An interesting method is based on the combination of fluorescence in situ hybridization (FISH) with microautoradiography (Lee et al. 1999, Ouverney \& Fuhrman 1999, Gray et al. 2000). How- ever, in most cases, FISH does not allow the use of species-specific probes because the abundance of a given species in a natural sample is usually too weak to allow its enumeration by epifluorescence microscopy. However, this approach remains of great interest for investigating the functional role of a dominant specific phylogenetic group (Zubkov et al. 2001). An alternative approach is the measurement of radioactive-tracer incorporation into flow cytometrically sorted cells (Servais et al. 1999). In this case, cells are sorted based on their physical properties; this allows the discrimination of bacterial sub-populations with different morphological or physiological states. Then, molecular and/or radioactive analyses can be performed on each 
cell-sorted fraction (Walner et al. 1997, Bernard et al. 2000, Fuchs et al. 2000), providing relevant information on groups participating in the biogeochemical processes.

The nucleic acid content of individual bacterial cells can be used to discriminate between 2 or more sub-populations within natural marine communities (Marie et al. 1997, Troussellier et al. 1999). Recent investigations have clearly shown that the cells with a high nucleic acid (HNA) content are the most active cells, and that they contribute to the most important part of community activity (Gasol et al. 1999, 2002, Lebaron et al. 2001). However, the cell-specific activity (CSA) of HNA cells is not homogeneously distributed within this subpopulation, since large cells are more active than small cells (Lebaron et al. 2002). In contrast, the cells with a low nucleic acid (LNA) content have very low CSA, and it was suggested that they may represent moribund or dead cells (Lebaron et al. 2002). If this is true, it means that from an ecological point of view, HNA cells are more relevant than LNA cells.

Recently, working on the Celtic Sea, Zubkov et al. (2001) have shown that these differences in terms of CSA should be considered with caution, since LNA cells may be at least as active as other members of the community and that in nutrient-limited waters they have the highest growth rates. The same authors reported that, although cells affiliated to the Cytophaga-Flavobacterium cluster had a high nucleic acid content and dominated in the surface mixed layer of the Celtic Sea, their growth rate was the lowest. Similarly, they showed that cells within the different subgroups discriminated by flow cytometry were affiliated to different phylogenetic clusters. These results are of great interest and should be validated by additional investigations. If we assume that LNA and HNA (low and high scatter) cells correspond to different phylogenetic groups, it means that some LNA cells may be active, and thus ecologically relevant, and that the LNA content of individual cells cannot be used as an absolute indicator of their real activity at the time of sampling.

The aim of this study was to investigate (1) the CSA and biomass-specific activity (BSA) of HNA and LNA cells from different aquatic ecosystems including marine (nearshore) and freshwaters, and (2) the genetic diversity within each cellular fraction. Activity of HNA and LNA cells was estimated by radioactive leucine incorporation followed by cell sorting using flow cytometry (Servais et al. 1999, 2001, Lebaron et al. $2001,2002)$. The genetic diversity of the bacterial natural assemblages, the HNA cells and the LNA cells was investigated using the SSCP (PCR single-strand conformation polymorphism) technique (Lee et al. 1996).

\section{MATERIALS AND METHODS}

Water samples. Samples were collected in April 2002 along the Mediterranean coast (France) at different sites in terms of their physico-chemical characteristics. A sample of freshwater was collected from the Tech river, $5 \mathrm{~km}$ above the river mouth $\left(42^{\circ} 35^{\prime} \mathrm{N}, 2^{\circ} 58^{\prime} \mathrm{E}\right)$ (April 8). A brackish water sample (salinity $14 \%$ ) was taken from the coastal Canet lagoon $\left(43^{\circ} 30^{\prime} \mathrm{N}\right.$, $3^{\circ} 54^{\prime}$ E) (April 10). Two seawater samples (nearshore samples) were collected from the Banyuls-sur-Mer harbor $\left(42^{\circ} 28^{\prime} \mathrm{N}, 3^{\circ} 08^{\prime} \mathrm{E}\right)$ on 2 different occasions (Harbor 1: April 9; Harbor 2: April 11). At each site, 51 were taken just below the surface and were processed in the laboratory within $4 \mathrm{~h}$ of collection. Natural samples were pre-filtered on $5 \mu \mathrm{m}$ pore-size membrane before subsequent analysis.

Enumeration of total bacterial cells, HNA and LNA cells by flow cytometry. For flow cytometric analyses, $1 \mathrm{ml}$ of $5 \mu \mathrm{m}$ pre-filtered and fixed natural sample was incubated with $0.5 \mu$ l of SYBR Green II (Molecular Probes) for $15 \mathrm{~min}$ at room temperature in the dark (Lebaron et al. 1998). Counts were performed with the FacsCalibur flow cytometer (Becton Dickinson) equipped with an air-cooled argon laser (488 nm, $15 \mathrm{~mW}$ ). Stained bacterial cells, excited at $488 \mathrm{~nm}$, were discriminated and enumerated according to their right-angle light scatter (SSC, related to cell size) and green fluorescence measured at 530/30 nm. The volume analyzed was around 10 to $15 \mu \mathrm{l}$. The subsequent cell concentration estimation was determined from the flow rate, which was calculated by weighing the sample before and after a 5 min run of the cytometer, corresponding to a volume of at least $50 \mu \mathrm{l}$. Fluorescent beads (1.002 $\mu \mathrm{m}$; Polysciences Europe) were systematically added to each analyzed sample to normalize cell fluorescence emission and light scatter values. In a plot of green fluorescence versus red fluorescence, we were able to distinguish photosynthetic prokaryotes from non-photosynthetic prokaryotes. The group of cells with a HNA content was discriminated from the group of cells with a LNA content. Each subgroup was delimited on the SSC versus green fluorescence plot by drawing a window (Fig. 1), and cell abundance was determined in each subgroup. The cytometric noise corresponded to particles which cannot be assigned to any population, and this noise was sometimes close to the LNA subgroup.

Biovolume and biomass per cell determination. In order to estimate the biovolume of HNA and LNA cells in the different studied samples, cell sizes were estimated from epifluorescence microscopy of HNA and LNA cells sorted using a FACSVantage SE flow cytometer (Becton Dickinson). This cytometer was used due to its high speed in sorting to obtain a suffi- 

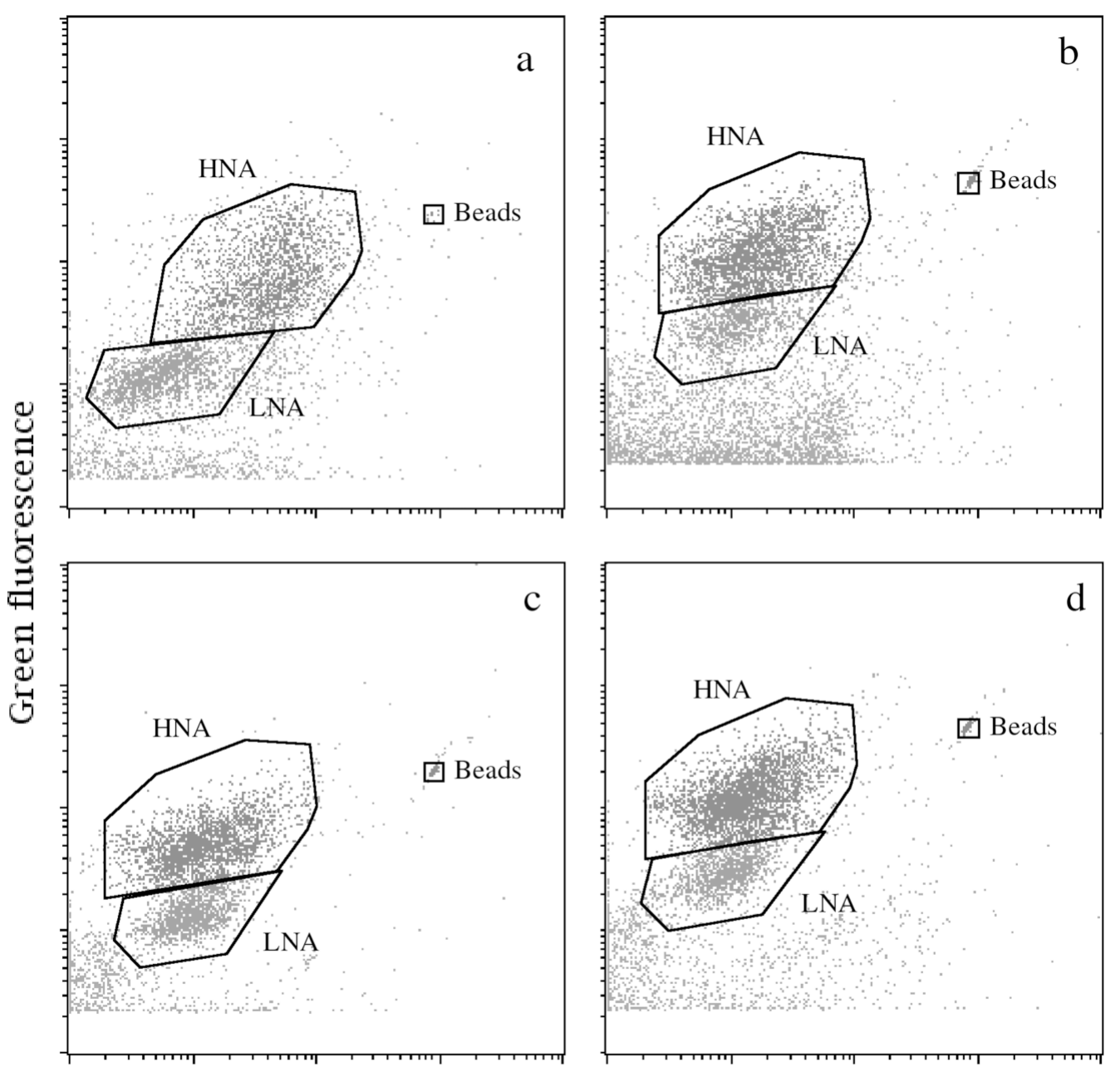

\section{Side scatter}

Fig. 1. Flow cytometric analysis (green fluorescence derived from SYBR Green II staining plotted against side scatter) of the water samples collected from (a) the Tech river, (b) the Canet lagoon, and (c,d) Banyuls-sur-Mer harbor (April 9 and 11, respectively). Cells with a high and low nucleic acid (HNA and LNA, respectively) content are delimited by a window reported on each cytogram. Total number of events plotted in (a) to (d) are: $12385 ; 41382 ; 13362$; and 11753 , respectively

cient number of sorted cells for microscopic enumeration and size measurement. The distribution of HNA and LNA cells in plots of green fluorescence versus relative SSC obtained with the FACSVantage SE flow cytometer was similar to that observed with the FACSCalibur.

Sorted cells were stained with 4',6-diamidino-4phenylindole (DAPI; $\left.1 \mu \mathrm{g} \mathrm{ml} \mathrm{ml}^{-1}, 30 \mathrm{~min}\right)$, filtered through a black polycarbonate membrane filter (0.2 $\mathrm{mm}$ pore-size, $25 \mathrm{~mm}$, Nuclepore), air-dried, mounted onto slides and examined with an Olympus AX70 epifluorescence microscope equipped with a CCD camera (Diagnostic Instruments). The length and width of 50 cells per sample were estimated by image analysis using the SPOT-RT software v 3.1 (Diagnostic
Instruments). Cell volumes were calculated assuming that the shape of bacteria was spherical or cylindrical with hemispheric ends. Bacterial biovolumes were converted to carbon content per cell using the relationship derived from Simon \& Azam (1989): $C=$ $92 \times V^{0.598}$, where $C$ represents the carbon content per cell (fg C cell-1) and $V$ the biovolume $\left(\mu \mathrm{m}^{3}\right)$.

In order to calibrate right-angle light scatter (SSC) of bacterial cells measured by flow cytometry, some additional bacterial subpopulations (high and low SSC subpopulations within the HNA and LNA fractions) were also sorted; the average biovolumes of these subpopulations were calculated as described above. Biovolumes were plotted versus SSC (Fig. 2) and the relationship between both parameters was used to 


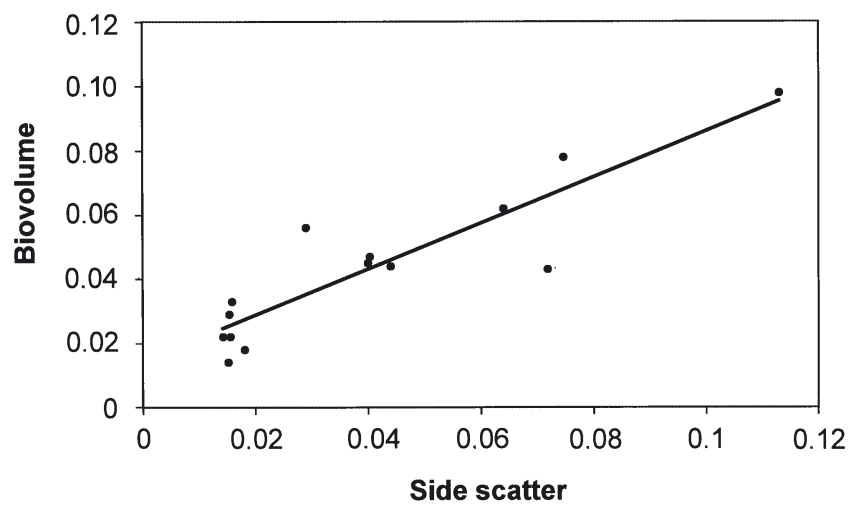

Fig. 2. Relationship between mean biovolume and mean side scatter of sorted subpopulations. Straight line correlation: $y=0.717 x+0.014\left(r^{2}=0.81, n=14\right)$

calculate biovolume from SSC of HNA and LNA cells for samples from previously published works (Lebaron et al. 2001, 2002), for which the biovolumes were not estimated by microscopy.

Leucine incorporation followed by cell sorting using flow cytometry. In order to estimate the contribution of HNA and LNA cells to total bacterial activity, we used a procedure similar to that developed by Servais et al. (1999) and applied by Lebaron et al. (2001, 2002). This procedure consisted of labeling bacteria with ${ }^{3} \mathrm{H}$-leucine and of sorting different bacterial subpopulations stained with SYBR Green II by flow cytometry in order to estimate the CSA of each sorted subpopulation. In this study, HNA and LNA cells were sorted after ${ }^{3} \mathrm{H}$-leucine labeling in order to determine the specific leucine incorporation rate of both subpopulations. Practically, leucine incorporation was

Table 1. Reproducibility of cell-specific activity (expressed as $\times 10^{-21}$ mol leucine cell-1 $\mathrm{h}^{-1}$ ) determined for the Tech river and Canet brackish-water coastal lagoon samples. HNA and LNA: high and low nucleic acid cells, respectively

\begin{tabular}{|lrcc|}
\hline Sample & Total & HNA cells & LNA cells \\
\hline Tech & & & \\
Replicate 1 & 435 & 776 & 23 \\
Replicate 2 & 538 & 798 & 31 \\
Average & 486 & 787 & 27 \\
SD & 73 & 16 & 6 \\
Relative error (\%) & 15 & 2 & 22 \\
Canet & & & \\
Replicate 1 & 387 & 588 & 135 \\
Replicate 2 & 373 & 655 & 149 \\
Replicate 3 & 358 & 665 & 141 \\
Average & 373 & 636 & 142 \\
SD & 15 & 42 & 7 \\
Relative error (\%) & 4 & 7 & 5 \\
\hline
\end{tabular}

performed at $80 \mathrm{nM}$ final concentration of ${ }^{3} \mathrm{H}$-leucine (151 $\mathrm{Ci} \mathrm{mmol}{ }^{-1}$, Amersham). This concentration was shown to saturate leucine incorporation in the different aquatic systems tested (data not shown). A $6 \mathrm{ml}$ sample was incubated at in situ temperature for $2 \mathrm{~h}$ in the dark and in the presence of ${ }^{3} \mathrm{H}$-leucine. Incubation was stopped by addition of formaldehyde ( $2 \%$ final concentration). Labeled bacteria were then stained with SYBR Green II following the procedure used to determine total counts. Labeled and stained bacterial cells were then sorted with the FacsCalibur flow cytometer in 2 windows (HNA and LNA cells) defined on the cytogram, where green fluorescence was plotted against SSC (Fig. 1). We selected the 'single sort mode' on the flow cytometer, where a sort occurs only if a single target cell is identified. The result gives high purity with less emphasis on recovery, and the most accurate counts of sorted cells. Sorted cells were thus enumerated and collected at the outlet of the flow cytometer directly onto a $0.2 \mu \mathrm{m}$ pore-size membrane (acetate cellulose Sartorius filter). The sort was ended when the number of sorted cells ranged between 150000 and 400000 cells to obtain a measurable radioactivity on the filter. Ten $\mathrm{ml}$ of cold $5 \%$ trichloroacetic acid (TCA) were added to the filter in order to precipitate macromolecules and to rinse the membrane. After $10 \mathrm{~min}$, TCA was eliminated by filtration and the filter was washed 3 times with $5 \mathrm{ml}$ of cold $5 \%$ TCA. The radioactivity associated with the sorted bacteria was then estimated by liquid scintillation. The average CSA of HNA and LNA cells (mol leucine incorporated cell ${ }^{-1} \mathrm{~h}^{-1}$ ) were determined by dividing the radioactivity incorporated by the bacteria sorted in the HNA and LNA subpopulations by the abundance of cells sorted in each subpopulation. The average BSA (expressed in mol leucine incorporated $\mu \mathrm{g} \mathrm{C}^{-1} \mathrm{~h}^{-1}$ ) were calculated by dividing CSA by the average carbon content per cell of the HNA and LNA cells.

To estimate the reproducibility of our procedure of CSA determination, the protocol was applied in duplicate on the Tech river sample and in triplicate on the Canet lagoon sample. The replicates of CSA estimates of HNA, LNA and total cells (cells sorted in a window including both HNA and LNA bacteria) are presented in Table 1. The relative error on CSA determination of the sorted populations ranged between 2 and $22 \%$ and was highest for LNA cells of the Tech sample which had the lowest CSA. From these analyses, the mean relative error on the CSA estimate was around $10 \%$ for cells with a high CSA (higher than $100 \times 10^{-21} \mathrm{~mol}$ leucine cell ${ }^{-1} \mathrm{~h}^{-1}$ ), although this relative error could be higher for cells with a lower CSA.

Nucleic acid amplification and SSCP fingerprinting analysis. For natural assemblages, $100 \mathrm{ml}$ of $5 \mu \mathrm{m}$ prefiltered non-labeled samples were filtered through 
$0.2 \mu \mathrm{m}$ polycarbonate filters and were stored at $-20^{\circ} \mathrm{C}$. For SSCP analysis of HNA and LNA bacteria, cells were sorted using the FACSVantage SE flow cytometer to obtain a sufficient number of sorted cells for molecular analysis in a reasonable sorting time. Between 1 and 2 million sorted cells were concentrated by centrifugation using eppendorf tubes (30 min, $14000 \mathrm{rpm}$ [21 920 $\times g$ ] in a microfuge at $4^{\circ} \mathrm{C}$ ). Some cells were missed after the centrifugation step, but selective loss was not expected because sorted fractions contained a quite homogeneous distribution of cell sizes and cells with certain characteristics, e.g. gas vesicles were not observed. The cell pellets were washed with $70 \%$ ethanol, centrifuged once more, and were then dried and stored at $-20^{\circ} \mathrm{C}$. The pellets were thawed and resuspended in $100 \mu \mathrm{l}$ of lysis buffer (40 mM EDTA, $50 \mathrm{mM}$ Tris- $\mathrm{HCl} \mathrm{pH}$ 8, $0.75 \mathrm{M}$ sucrose). Lysozyme was then added (1 $\mathrm{mg}$ $\mathrm{ml}^{-1}$ final concentration) and the suspension was incubated at $37^{\circ} \mathrm{C}$ for $45 \mathrm{~min}$. After the addition of Proteinase $\mathrm{K}\left(0.2 \mathrm{mg} \mathrm{ml}^{-1}\right.$ final concentration) and sodium dodecyl sulfate ( $1 \%$ final concentration), the samples were incubated at $55^{\circ} \mathrm{C}$ for $1 \mathrm{~h}$. Polycarbonate filters followed the same procedure. DNA was then extracted with an equal volume of phenol-chloroform-isoamyl alcohol (25:24:1, v:v:v) and was precipitated by the addition of $1 / 10$ of the volume of $3 \mathrm{M}$ sodium acetate and 2 volumes of cold isopropanol followed by incubation for $3 \mathrm{~h}$ at $-20^{\circ} \mathrm{C}$. The DNA was recovered by centrifugation at $10000 \times g$ for $30 \mathrm{~min}$ and the pellet was washed with cold $70 \%$ ethanol, dried, and resuspended in $20 \mu \mathrm{l}$ of sterile distilled water. After such washing and extraction steps, potential artifacts/problems created by the stains in the PCR reaction were circumvented.

For PCR amplification, the bacterial primers W49 dir (Escherichia coli Position 331; 5'-ACG-GTC-CAGACT-CCT-ACG-GG-3') and W34 rev (E. coli Position 533; 5'-TTA-CCG-CGG-CTG-CTG-GCA-C-3'); 5' labeling with tetrahydrochloro-6-carboxy-fluorescein (TET) (Applied Biosystems) were used. Both primers targeted universal 16S rRNA regions for bacteria and the amplified region has been widely used by other authors (e.g. Muyzer et al. 1993). The PCR program started first by a cycle of 2 min at $94^{\circ} \mathrm{C}$, followed by 28 standard cycles at $61^{\circ} \mathrm{C}$ annealing temperature. $\mathrm{PCR}$ reactions were carried out with Pfu polymerase (PROMEGA). More details on the PCR procedure are given in Delbès et al. (2000). PCR products (ca. 200 bp length) were checked on a $2 \%$ agarose gel and further purified with QIAGEN columns (QIAquick PCR purification kit). For SSCP fingerprinting analysis, PCR products were heat denatured at $94^{\circ} \mathrm{C}$ for $5 \mathrm{~min}$ and immediately placed on ice for at least $10 \mathrm{~min}$. A fluorescently labeled internal size marker was added (Genescan-400 Rox, Applied Biosystems). The size standard contains a different fluorophore (Rox) and permits, after computing correction, a reliable comparison of patterns from each sample. SSCP electrophoresis was carried out as previously described (Delbès et al. 2000) using the ABI 310 Genetic Analyzer equipped with a capillary tube (Applied Biosystems).

\section{RESULTS}

\section{Cell- and biomass-specific activities of HNA and LNA cells}

For the 4 studied samples, flow cytometric analysis of bacterial cells after SYBR Green II staining allows discrimination of HNA and LNA cells according to their right-angle light scatter (related to cell size) and to their green fluorescence (related to the nucleic acid content of the cells) (Fig. 1). Total bacterial counts var-

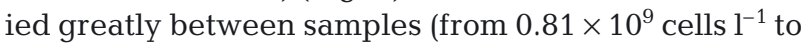
$8.82 \times 10^{9}$ cells $^{-1}$ ), and the contribution of HNA cells to total numbers ranged between 43 and $70 \%$ (Table 2). The mean biovolume of HNA and LNA cells was determined on the basis of cell size measured by epifluorescence microscopy coupled with image analysis on both HNA and LNA cell-sorted fractions. As expected, HNA cells (biovolume in the range 0.044 to $0.078 \mu^{3}$ ) were larger (from 1.6- to 5.6-fold) than LNA cells (biovolume in the range 0.014 to $0.029 \mu^{3}$ ). From these biovolumes, we determined the mean carbon content per

Table 2. Bacterial abundance, biovolume, biomass and activity of cells with a high and low nucleic acid (HNA and LNA, respectively) content in different water samples analyzed. When justified, the relative contribution of each fraction to the total community is reported in brackets. Samples from Harbors 1 and 2 are from Banyuls-sur-Mer harbor

\begin{tabular}{|c|c|c|c|c|c|c|c|c|}
\hline & \multicolumn{2}{|c|}{$\begin{array}{l}\text { Cell number } \\
\left(\times 10^{9} \mathrm{l}^{-1} ; \%\right)\end{array}$} & \multicolumn{2}{|c|}{$\begin{array}{l}\text { Biovolume } \\
\left(\mu \mathrm{m}^{3} \mathrm{cell}^{-1}\right)\end{array}$} & \multicolumn{2}{|c|}{$\begin{array}{c}\text { Biomass } \\
\left(\mu \mathrm{C}^{-1} ; \%\right)\end{array}$} & \multicolumn{2}{|c|}{$\begin{array}{c}\text { Activity } \\
\left(\times 10^{-9} \text { mol leucine } \mathrm{l}^{-1} \mathrm{~h}^{-1} ; \%\right)\end{array}$} \\
\hline & HNA & LNA & HNA & LNA & HNA & LNA & HNA & LNA \\
\hline Tech river & $1.21(62)$ & $0.74(38)$ & 0.078 & 0.014 & $24.2(82)$ & $5.3(18)$ & $952.4(98)$ & $19.7(2)$ \\
\hline Canet lagoon & 3.37 (43) & $4.45(57)$ & 0.045 & 0.022 & $48.5(54)$ & $41.8(46)$ & $2142.6(77)$ & $629.9(23)$ \\
\hline Harbor 1 & $0.62(70)$ & $0.27(30)$ & 0.044 & 0.022 & $8.8(78)$ & $2.5(22)$ & $301.0(93)$ & $21.4(7)$ \\
\hline Harbor 2 & $0.52(64)$ & $0.29(36)$ & 0.047 & 0.029 & $7.7(71)$ & $3.2(29)$ & $211.3(89)$ & 26.9 (11) \\
\hline
\end{tabular}


Table 3. Cell-specific (CSA) and biomass-specific activity (BSA) for high and low nucleic acid (HNA and LNA, respectively) cells in samples analyzed in cell sorting experiments with bacteria from different aquatic systems. The first 4 samples correspond to the experiments fully described in this paper, the others are results recalculated from data presented in Lebaron et al. (2001, 2002). SOLA station samples were collected from the bay of Banyuls-sur-Mer; Harbor 1 and 2 samples from Banyuls-sur-Mer harbor

\begin{tabular}{|c|c|c|c|c|c|c|}
\hline \multirow[t]{2}{*}{ Samples } & \multicolumn{3}{|c|}{$-\mathrm{CSA}$} & \multicolumn{3}{|c|}{ - BSA } \\
\hline & \multicolumn{3}{|c|}{$\left(\times 10^{-21} \mathrm{~mol}\right.$ leucine cell $\left.{ }^{-1} \mathrm{~h}^{-1}\right)$} & \multicolumn{2}{|c|}{$\left(\times 10^{-6}\right.$ mol leucine $\left.\mathrm{g} \mathrm{C}^{-1} \mathrm{~h}^{-1}\right)$} & HNA:LNA \\
\hline Tech river & 787.1 & 26.6 & 29.6 & 39.3 & 3.7 & 10.6 \\
\hline Canet lagoon & 635.8 & 141.6 & 4.5 & 44.1 & 15.1 & 2.9 \\
\hline Harbor 1 & 485.5 & 79.4 & 6.1 & 34.2 & 8.5 & 4.0 \\
\hline Harbor 2 & 406.3 & 92.9 & 4.4 & 27.5 & 8.4 & 3.3 \\
\hline Tech river $1^{\mathrm{a}}$ & 75.0 & 6.0 & 12.5 & 4.9 & 0.6 & 7.5 \\
\hline Tech river $2^{\mathrm{a}}$ & 408.1 & 5.5 & 74.2 & 27.3 & 0.6 & 43.6 \\
\hline Tech river $3^{\mathrm{a}}$ & 233.0 & 13.0 & 17.9 & 17.4 & 1.4 & 12.7 \\
\hline Harbor $^{\mathrm{a}}$ & 464.0 & 29.0 & 16.0 & 33.8 & 2.8 & 12.2 \\
\hline SOLA $1^{\mathrm{a}}$ & 68.0 & 25.0 & 2.7 & 6.1 & 2.5 & 2.4 \\
\hline SOLA $2^{\mathrm{a}}$ & 59.0 & 15.6 & 3.8 & 5.1 & 1.5 & 3.3 \\
\hline Harbor $^{b}$ & 258.7 & 25.2 & 10.3 & 21.3 & 2.5 & 8.6 \\
\hline
\end{tabular}

cell, which varied from 7.2 to $11.1 \mathrm{fg} \mathrm{C}$ cell $^{-1}$ and from 14.2 to $20 \mathrm{fg} \mathrm{C} \mathrm{cell}^{-1}$ for LNA and HNA cells, respectively. As HNA cells were larger than LNA cells, their contribution to the total bacterial biomass (from 54 to

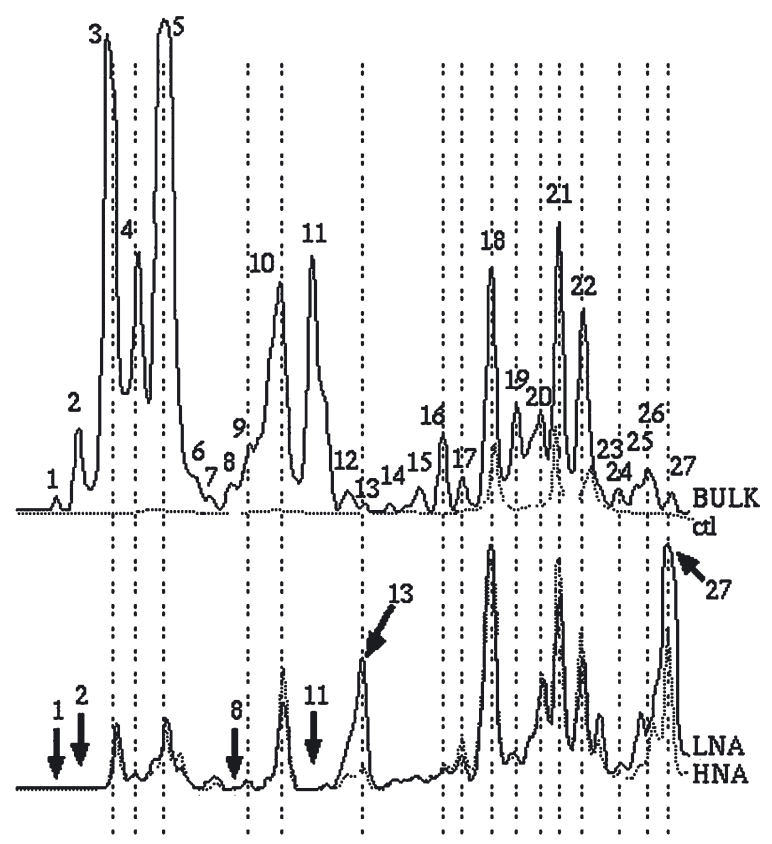

Fig. 3. SSCP (PCR single-strand conformation polymorphism) fingerprints of the total bacterial population, the high and low nucleic acid (HNA and LNA, respectively) cells from the sample collected in the Banyuls-sur-Mer harbor (Harbor 1: April 9). Numbered peaks appear for the entire community and ' $c t l$ ' is a control for contamination added during the manipulation process. Arrows indicate missed peaks in the sorted fraction (Peaks 1, 2, 8, and 11) or peaks that increase their relative abundance in the sorted fraction (Peaks 13 and 27)
$82 \%$ ) was higher than their contribution to the abundance (Table 2). In all samples, HNA cells have a dominant contribution to the production of the total community (ranging from 77 to $98 \%$ ).

Cell size measurements were also performed on several other cell-sorted fractions using epifluorescence microscopy coupled with image analysis. A significant correlation $\left(\mathrm{r}^{2}=0.81, \mathrm{n}=14, \mathrm{p}<0.01\right)$ was found between mean biovolumes and the mean relative right-angle light scatter (average SSC of the bacteria divided by the SSC of the fluorescent beads) of the sorted cells (Fig. 2).

Coupling cell sorting with radioactive leucine labeling allows us to calculate the CSA per HNA and LNA cell. For the 4 samples analyzed, the CSA of HNA cells (from 406 to $787 \times 10^{-21} \mathrm{~mol}$ leucine cell ${ }^{-1} \mathrm{~h}^{-1}$ ) was largely higher (from 4.4 to 29.6 times) than the CSA of LNA cells (from 27 to $141 \times 10^{-21} \mathrm{~mol}$ leucine cell ${ }^{-1} \mathrm{~h}^{-1}$ ) (Table 3). Considering the carbon content per HNA and LNA cell (Table 2), the BSA was calculated. For each sample the BSA of HNA cells was still significantly higher (2.9 to 10.6 times) than that of LNA cells (Table 3).

In order to increase the set of data for the comparison of BSA of HNA and LNA bacteria, we did the same calculation on samples for which we previously determined the CSA using the same experimental protocol (Lebaron et al. 2001, 2002). As the biovolumes of HNA and LNA cells were not experimentally measured for these samples, they were calculated from the average relative SSC of the sorted subpopulations using the relationship reported in Fig. 2. The carbon content of HNA and LNA cells was deduced from the calculated biovolumes and BSAs were estimated from the CSA. 
All the data for CSA and BSA are reported in Table 3. In each situation recorded in Table 3, due to the larger cell size of HNA cells, the ratio of BSA of HNA cells to BSA of LNA cells was lower than the ratio of CSA of HNA cells to CSA of LNA cells. But in all cases, the ratio of BSA of HNA cells to BSA of LNA cells remained significantly higher than 1 (between 2.4 and 43.6), suggesting that the growth rate (biomass production per biomass unit) of HNA cells was higher than that of LNA cells in all investigated samples.

\section{SSCP fingerprinting}

PCR amplifications of bacterial 16S rRNA genes were obtained from the natural assemblages of all 3 sites (Tech river, Canet lagoon and Banyuls-sur-Mer harbor) and from the sorted fractions of HNA and LNA cells of harbor and river samples. We did not succeed with PCR amplification from sorted cells of the Canet lagoon. Both natural assemblages and sorted HNA/ LNA fingerprints were directly compared for the harbor samples and the Tech river sample. Fig. 3 shows the pattern of peaks for the Harbor 1 sample, whereas Table 4 gives the total number of peaks for each sample and correspondence (or lack of correspondence) between the SSCP profile of a given natural assemblage with those obtained for the corresponding LNA and HNA fractions. For river and harbor samples, differences found between the species in the natural assemblage and those present in the 2 sorted fractions (HNA and LNA cells) corresponded mainly to minor peaks. In all cases, several peaks (4 to 7 peaks) were missed in the sorted fraction (indicated by arrows in Fig. 3 and listed in Table 4), whereas in one case (Tech river sample), a few minor peaks were detected in the sorted fraction of both HNA and LNA that were not found in the original assemblage. For the natural assemblages, the number of peaks in the SSCP densitogram ranged from 25 to 27 , and from 19 to 23 peaks for the sorted fractions (Table 4).

\section{DISCUSSION}

\section{Cell- and biomass-specific activities of HNA and LNA cells}

Flow cytometry usually allows 2 to 3 different subpopulations of cells within natural aquatic bacterial communities to be discriminated based on their SSC characteristics (related to cell size) and green fluorescence (related to the nucleic acid content of cells when previously stained with a fluorescent nucleic acid dye) (Troussellier et al. 1999, Gasol \& del Giorgio 2000). In this study, we were able to discriminate HNA and LNA cells in marine, brackish and freshwater samples. The contribution of HNA cells to total bacterial counts ranged from 43 to $70 \%$; this range is in agreement with the values reported by Lebaron et al. (2001) in similar environments and those mentioned by Moran et al. (2002) for various areas of the Atlantic Ocean. Several authors have recently suggested that HNA cells are more active than LNA cells (Gasol et al. 1999) and that they are responsible for most of the bacterial production (Lebaron et al. 2001) even if their CSA is highly

Table 4. Data of the SSCP (PCR single-strand conformation polymorphism) analysis of the natural bacterial assemblage and of the high and low nucleic acid (HNA and LNA, respectively) sorted cells for the 4 studied samples (number of peaks for each sample analyzed and correspondence of peaks observed for the HNA and LNA cells with regards to the natural assemblage). Samples from Harbors 1 and 2 are from Banyuls-sur-Mer harbor. nd: not determined

\begin{tabular}{|c|c|c|c|}
\hline Sample & Natural assemblage & HNA cells & LNA cells \\
\hline \multicolumn{4}{|l|}{ Tech river } \\
\hline No. of peaks & 26 & 22 & 22 \\
\hline Peak correspondence & Peaks T1 to T26 & $\begin{array}{c}\text { Lack peaks T7, T8, T12, } \\
\text { T13, T18, T25, T26 } \\
+3 \text { additional peaks }\end{array}$ & $\begin{array}{c}\text { Lack peaks T7, T8, T12, } \\
\text { T13, T18, T25, T26 } \\
\text { + } 3 \text { additional peaks }\end{array}$ \\
\hline \multicolumn{4}{|l|}{ Canet lagoon } \\
\hline No. of peaks & 25 & nd & nd \\
\hline Peak correspondence & Peaks C1 to C25 & - & - \\
\hline \multicolumn{4}{|l|}{ Harbor 1} \\
\hline No. of peaks & 27 & 23 & 23 \\
\hline Peak correspondence & Peaks H1 to H27 & Lack peaks H1, H2, H8, H11 & Lack peaks H1, H2, H8, H11 \\
\hline \multicolumn{4}{|l|}{ Harbor 2} \\
\hline No. of peaks & 27 & 20 & 19 \\
\hline Peak correspondence & Peaks H'1 to H'27 & $\begin{array}{c}\text { Lack peaks } \mathrm{H}^{\prime} 1, \mathrm{H}^{\prime} 2, \mathrm{H}^{\prime} 4, \mathrm{H}^{\prime} 5 \\
\mathrm{H}^{\prime} 7, \mathrm{H}^{\prime} 8, \mathrm{H}^{\prime} 11\end{array}$ & $\begin{array}{l}\text { Lack peaks } \mathrm{H}^{\prime} 1, \mathrm{H}^{\prime} 2, \mathrm{H}^{\prime} 4 \\
\mathrm{H}^{\prime} 5, \mathrm{H}^{\prime} 7, \mathrm{H}^{\prime} 8, \mathrm{H}^{\prime} 10, \mathrm{H}^{\prime} 11\end{array}$ \\
\hline
\end{tabular}


heterogeneous (Lebaron et al. 2002). This study confirmed the dominant contribution of HNA cells to the production of the total bacterial community, regardless of the type of aquatic system investigated (marine, brackish or freshwater) (Table 2). The ratio between CSA of HNA cells and CSA of LNA cells was lower in the case of the SOLA station samples (samples collected in the Bay of Banyuls-sur-Mer at $3 \mathrm{~m}$ depth). These samples correspond to more oligotrophic waters in which the difference of fluorescence of HNA and LNA cells was also the lowest. Generally, if HNA cells dominate the activity of the bacterial community, they may also play a significant role in the carbon cycle, and the question of their genetic diversity and identification is of great importance to better relate bacterial community structure and functions in the natural environment.

The flow sorting technique which combines leucine incorporation and nucleic acid staining has proved to be an effective approach to investigating the CSA of HNA and LNA cells, since the average coefficients of variation of CSA determined from replicates were quite low (on average 4.4 and $12.8 \%$ for HNA and LNA cells, respectively). In this study, we confirmed that the CSA (leucine incorporation rate) of HNA cells was higher than that of LNA cells. Working on the Celtic Sea and combining ${ }^{35} \mathrm{~S}$ methionine incorporation with cell sorting by flow cytometry, Zubkov et al. (2001) also found that the CSA of HNA cells was higher than that of LNA cells. They explained the higher cellular protein synthesis rate of HNA cells by their need to maintain a larger cellular protein content since they found similar BSA for HNA and LNA cells.

In this paper, we estimated the cell size and carbon content of HNA and LNA cells in order to calculate BSA for both subpopulations. We also used previous data (Lebaron et al. 2001, 2002) obtained on the relative SSC and CSA (using the leucine incorporation method and the cell sorting procedure) but for which cell size and carbon content per cell were not available. Therefore, these values were estimated from the relationship provided in this study between the relative SSC and cell biovolume of sorted cells (Fig. 2). This relationship was established on the basis of microscopic measurements and was quite different from the one reported by Troussellier et al. (1999). These authors established their relationship for bacterial cells sampled in an enriched mesocosm in which cells were more active, and bacterial biovolumes reported by Troussellier et al. (1999) were significantly higher than those found in the study.

The data obtained in this study clearly showed that the BSA of HNA cells was in all cases higher than that of LNA cells. Of course, the BSA of both HNA and LNA cells depend on the values of carbon content per cell used for the calculation. In this study, we used the relationship between cellular carbon content and biovolume derived from Simon \& Azam (1989). Nevertheless, a similar trend was observed when the calculation was made using the relationship provided by Lee \& Fuhrman (1987). This latter calculation also showed that the BSA of HNA cells was in all cases significantly higher that the BSA of LNA cells (data not shown).

This clearly indicates that the difference in CSA between HNA and LNA cells cannot be explained only by a difference in the size of the cellular pool of protein between LNA and HNA cells as suggested by Zubkov et al. (2001) from their measurements in the Celtic Sea. Our data suggest that the growth rates (proportional to BSA) of the HNA cells were significantly higher than those of LNA cells. Even if LNA cells cannot be considered as dead cells, as their specific activities (per cell and per biomass unit) were significantly different from zero, our data imply that the HNA cells are the dynamic members of the bacterial community and are of major importance in biogeochemical processes in the various aquatic systems studied. From the data reported by both Zubkov et al. (2001) and Lebaron et al. (2002), we can assume that both LNA and HNA cells are heterogeneous and that the LNA fraction may contain both dead cells and a few active cells. Recently, very small bacteria (called ultramicrobacteria) were found to be active in oceans and freshwaters (Rappé et al. 2002, Hahn et al. 2003). Therefore, although their contribution to the community activity remains low, the LNA cells may contain a few bacterial species with high specific growth rates. The identification of such species was beyond the scope of this study and will be addressed in forthcoming work.

\section{Genetic diversity of HNA and LNA cells}

Fingerprinting methods like SSCP allow the separation of DNA fragments of the same size but with a different base composition, providing a rapid picture of the most abundant 16S rDNA sequences within a community of PCR-amplified 16S rDNAs. In this study, the method was used to compare the SSCP patterns from the natural bacterial community with those of both LNA and HNA cell-sorted fractions. In all cases, the SSCP patterns from HNA and LNA fractions were very similar. However, some bacterial species found in profile from the unsorted community were not detected in both LNA and HNA fractions. This is probably due to the fact that we analyzed 100 times more cells in the natural assemblage $\left(\times 10^{8}\right.$ cells $)$ than in the sorted fractions $\left(\times 10^{6}\right.$ cells $)$, and these undetected populations in the sorted fractions might correspond to minor populations. It is also possible that some major peaks from the 
natural assemblages which were not detected in the sorted fractions (e.g. peak 11) correspond to 16S rRNA genes from algal chloroplasts that are also amplified with the 'bacterial-specific' primer set. Unfortunately, direct sequencing of SSCP peaks is not possible: labeled 16S rDNA fragments pass throughout the capillary, are detected by the laser and are poured away from the system. Therefore, SSCP peaks are only visible and available on the screen of the computer. In order to identify the species which correspond to each peak, an extensive cloning approach linked to SSCP fingerprinting should be carried out (Delbès et al. 2000). For certain minor peaks found in the unsorted community profile (such as Peaks 27 and 13) we observed that they gave large peaks in the LNA profiles but not to the same extent in the HNA profiles (see Fig. 3). This may indicate quantitative differences for a few populations within the HNA and LNA fractions. Conversely, additional minor peaks appeared in both HNA and LNA subpopulations, but not in the bulk community (Tech river samples, Fig. 3). In that case, because a few major peaks were missed in such sorted fractions, relative proportions in the new DNA mixture would have changed and minor populations would increase their relative contribution to a level above the threshold of the fingerprinting technique (and would therefore now be 'visible' in the fingerprints). The combination of cell sorting techniques with molecular techniques remains limited in some applications due to the difficulty of sorting large numbers of cells.

The similarity of the SSCP patterns of HNA and LNA cells indicates that both groups were mainly composed of the same species. Our findings suggest that in these natural aquatic ecosystems, most bacterial populations, or at least the dominant populations, are divided into 2 categories of cells depending on their nucleic acid content. This means that phylogenetically identical cells can be found in the natural environments in very different physiological states, resulting in cells with very different apparent nucleic acid contents and biovolumes. Lebaron et al. (2002), working on 10 pure strains isolated from the marine environment, showed that in late stationary phase, HNA and LNA cells can be easily distinguished; the average ratio of fluorescence between HNA and LNA cells of the different stains was equal to 16 and the ratio of biovolume equal to 4 , demonstrating that cells within a given population can have very different biovolumes and apparent nucleic acid contents. The heterogeneity of the physiological state at the cellular level in the natural environments is congruent with heterogeneity of the distribution of resources at the microscale, which may result in physiological heterogeneity within marine bacterial populations.

However, these results are not consistent with those reported by Zubkov et al. (2001), who suggested that in natural bacterial communities of the Celtic Sea, each cellular fraction was dominated by different phylogenetic groups. Although their findings were only based on probing with a few group-specific probes, such a heterogeneity was not reported by these authors for species affiliated to the $\alpha$-proteobacteria and the Cytophaga-Flavobacterium cluster. In the present study, the species were not identified but previous studies have already demonstrated the dominance of both $\alpha$-proteobacteria and the Cytophaga-Flavobacterium species in some of the waters sampled in this study (Mediterranean Sea) (Pukall et al. 1999a,b, Schäfer et al. 2001). The discrepancy between the data of both studies does not seem to be explained by the difference of experimental approaches, since the approach using a lower phylogenetic resolution would show more homogeneity in the populations and mask differences that might be detected using a more discriminating method. In constrat, Zubkov et al. (2001) noted, using broad specificity probes (phylum/subphylum level probes), that active and inactive fractions were phylogenetically distinct, whereas in the present study, using a higher resolution method to analyze the communities, active and inactive fractions had a similar community composition. If the difference in experimental approaches cannot explain the differences found between the 2 studies, they are more likely due to the fact that the natural ecosystems studied were very different. For instance, Zubkov's study was conducted on samples from the Celtic Sea (North Atlantic), including deep sea waters, while our study was performed on more eutrophic waters, marine samples collected from the harbor of Banyuls-sur-Mer, brackish water collected from a eutrophic lagoon, and freshwater collected from a river. According to the SSCP results, we may consider that physiological heterogeneity dominates the natural bacterial communities of the environments sampled in the present study, and that the HNA fraction of cells remains of great ecological relevance.

\section{CONCLUSIONS}

Data gained in this study on marine, brackish and freshwater using a procedure coupling radioactive labeling and cell sorting confirmed previous results, showing that the bacteria with a HNA content have a higher leucine incorporation rate per cell than the bacteria with a LNA content. Estimation of the carbon content per cell of both HNA and LNA cells by measuring the biovolume of sorted cells allows BSA to be calculated. In this study, BSA of HNA cells was always significantly higher than BSA of LNA cells, and HNA cells bring a dominant contribution to the 
production of the total community. SSCP analysis of 16S rDNA genes from the bulk community, HNA and LNA cellular fractions has revealed that HNA and LNA subpopulations were composed of the same dominant species, and thus most natural populations were characterized by a large heterogeneity of cellular physiological states (from dead, inactive or very weakly active bacteria belonging to the LNA cells pool, to more or less active bacteria from the same taxa belonging to the pool of HNA cells). However, the fact that the activity of the LNA cells pool was not equal to zero may be due to some minor species exhibiting leucine incorporation and having a small genome size. The identification of these species should be of great interest.

Acknowledgements. This work was performed within the scope of a French-Belgian cooperation project (CGRI-FNRSCNRS research project). The cell sorter was partly funded by the EU (AIRWIN EVK3-CT20000-00030) and partly by grants from the Région Languedoc-Roussillon and from the French National Institute of Research (CNRS).

\section{LITERATURE CITED}

Bernard L, Schäfer H, Joux F, Courties C, Muyzer G, Lebaron P (2000) Genetic diversity of total, active and culturable marine bacteria in coastal seawater. Aquat Microb Ecol 23:1-11

Delbès C, Moletta R, Godon JJ (2000) Monitoring of activity dynamics of an anaerobic digester bacterial community using 16S rRNA polymerase chain reaction-single-strand conformation polymorphism analysis. Environ Microbiol 2:506-515

Fuchs BM, Zubkov MV, Sahm K, Burkill PH, Amann R (2000) Changes in community composition during dilution cultures of marine bacterioplankton as assessed by flow cytometric and molecular biological techniques. Environ Microbiol 2:191-201

Gasol JM, del Giorgio PA (2000) Using flow cytometry for counting natural planktonic bacteria and understanding the structure of planktonic bacterial communities. Sci Mar 64:197-224

Gasol JM, Zweifel UL, Peters F, Furhman JA, Hagström ^̊ (1999) Significance of size and nucleic acid content heterogeneity as measured by flow cytometry in natural planktonic bacteria. Appl Environ Microbiol 65: 4475-4483

Gasol JM, Comerma M, Garci JC, Armengol J, Casamayor EO, Kojecka P, Šimek K (2002) A transplant experiment to identify the factors controlling bacterial abundance, activity, production and community composition in a eutrophic canyon-shaped reservoir. Limnol Oceanogr 47:62-77

Gray ND, Howath R, Pickup RW, Gwyn Jones J, Head IM (2000) Use of combined microautoradiography and fluorescence in situ hybridization to determine carbon metabolism in mixed natural communities of uncultured bacteria from the genus Achramatium. Appl Environ Microbiol 66:4518-4522

Hahn MW, Lünsdorf $H, W u$, Schauer M, Höfle MG, Boenigk J, Stadler P (2003) Isolation of novel ultramicrobacteria classified as Actinobacteria from five fresh- water habitats in Europe and Asia. Appl Environ Microbiol 69:1442-1451

Lebaron P, Parthuisot N, Catala P (1998) Comparison of blue nucleic acid dyes for the flow cytometric enumeration of bacteria in aquatic systems. Appl Environ Microbiol 64: $1724-1730$

Lebaron P, Servais P, Agogue H, Courties C, Joux F (2001) Does the high nucleic acid content of individual bacterial cells allow us to discriminate between active cells and inactive cells in aquatic systems? Appl Environ Microbiol 67:1775-1782

Lebaron P, Servais P, Baudoux AC, Bourrain M, Courties C, Parthuisot N (2002) Variations of bacterial specific activity with cell-size and nucleic acid content assessed by flow cytometry. Aquat Microb Ecol 28:131-140

Lee DH, Zo YG, Kim SJ (1996) Nonradioactive method to study the genetic profiles of natural bacterial communities by PCR-single-strand-conformation polymorphism. Appl Environ Microbiol 62:3112-3120

Lee N, Nielsen PH, Andreasen KH, Juretschko S, Nielsen JL, Schleiffer KH, Wagner M (1999) Combination of fluorescent in situ hybridization and microautoradiography: a new tool for structure-function analyses in microbial ecology. Appl Environ Microbiol 65:1289-1297

Lee S, Fuhrman JA (1987) Relationships between biovolume and biomass of naturally derived marine bacteriplankton. Appl Environ Microbiol 53:1298-1303

Marie D, Partenski F, Jacquet S, Vaulot D (1997) Enumeration and cell cycle analysis of natural populations of marine picoplankton by flow cytometry using the nucleic acid stain SYBR Green I. Appl Environ Microbiol 63:186-193

Moran XAG, Gasol JM, Pedros-Alio C, Estrada M (2002) Partitioning of phytoplanktonic organic carbon production and bacterial production along a coastal-offshore gradient in the NE Atlantic during different hydrographic regimes. Aquat Microb Ecol 29:239-252

Muyzer G, de-Waal EC, Uitterlinden AG (1993) Profiling of complex microbial populations by denaturing gradient gel electrophoresis analysis of polymerase chain reaction amplified genes coding for 16S rRNA. Appl Environ Microbiol 59:695-700

Ouverney CC, Fuhrman JA (1999) Combined microautoradiography-16S rRNA probe technique for determination of radioisotope uptake by specific microbial cell types in situ. Appl Environ Microbiol 65:1746-1752

Pukall R, Päuker O, Buntefuß D, Ulrichs G and 5 others (1999a) High sequence diversity of Alteromonas macleodii-related cloned and cellular 16S rDNAs from a Mediterranean seawater mesocosm experiment. FEMS Microbiol Ecol 28:335-344

Pukall R, Buntefuß D, Frühling A, Rohde $M$ and 5 others (1999b) Sulfitobacter mediterraneus sp. nov., a new sulfite-oxidizing member of the $\alpha$-Proteobacteria. Int J Syst Bacteriol 49:513-519

Rappé MS, Connon KL, Vergin KL, Giovannoni (2002) Cultivation of the ubiquitous SAR 11 marine bacterioplankton clade. Nature 418:630-633

Schäfer H, Bernard L, Courties C, Lebaron P and 7 others (2001) Microbial communities dynamics in Mediterranean nutrient enriched seawater mesocosms: changes in the genetic diversity of bacterial populations. FEMS Microbiol Ecol 35:243-253

Servais P, Courties C, Lebaron P, Troussellier M (1999) Coupling bacterial activity measurements with cell sorting by flow cytometry. Microb Ecol 38:180-189

Servais P, Agogué H, Courties C, Joux F, Lebaron P (2001) Are the actively respiring cells (CTC+) those responsible 
for bacterial production in aquatic environments? FEMS Microbiol Ecol 35:171-179

Simon M, Azam F (1989) Protein content and protein synthesis rates of planktonic marine bacteria. Mar Ecol Prog Ser 51:201-213

Troussellier M, Courties C, Lebaron P, Servais P (1999) Flow cytometric discrimination of bacterial populations in seawater based on SYTO 13 staining of nucleic acids. FEMS

Editorial responsibility: Jed Fuhrman,

Los Angeles, California, USA
Microbiol Ecol 29:319-330

Walner G, Fuchs B, Spring S, Beisker W, Amann R (1997) Flow sorting of microorganisms for molecular analysis. Appl Environ Microbiol 63:4223-4231

Zubkov MV, Fuchs, B, Burkill PH, Amann R (2001) Comparison of cellular and biomass specific activities of dominant groups in stratified waters of the Celtic Sea. Appl Environ Microbiol 67:5210-5218

Submitted: December 18, 2002; Accepted: May 6, 2003

Proofs received from author(s): July 15, 2003 